\title{
An Analysis of Potential Sensitive Plant Species FOR LONG-TERM MONITORING IN Glacier National PARK
}

\author{
BRIAN A. MAUER $\bullet$ TARA Y. WILLIAMS \\ DEPARTMENT OF ZOOLOGY $\bullet$ BRIGHAM YOUNG UNIVERSITY \\ PROVO
}

\section{$\checkmark \quad$ INTRODUCTION}

Monitoring of the natural resources available in parks is necessary to allow the National Park Service to develop long term management strategies for preservation of those resources for future generations. To this end, personnel at Glacier National Park (GLAC) determined that it was necessary to identify populations of plant species that might serve as indicators of environmental change. Preliminary data on locations of populations of sensitive plants was obtained by the park from work done by Lesica (1984). However, basic life history data on these species had not been collected and made available to park personnel in such a manner as to interface with existing park data bases. The acquisition of such data was seen as a necessary step in developing a baseline data base that park personnel could use to base future assessments of biological change within the park.

The objective of the research described in this final report was to obtain basic life history data from the literature for 52 species of plant populations in GLAC judged to be rare or endangered, and hence potentially sensitive to changes in the biological and environmental conditions in the park. To accomplish this objective, we used the list of rare plant species given by Lesica (1984; Table 1 of this report) with recent additions by the Montana Natural Heritage Program (1990) as the basis of a literature search to determine the basic life history attributes of each species. We used these data and the locations of populations of each species to document the spatial distribution of the different ecological groups represented by the rare flora of the park. This suggested that park personnel should focus on continued attempts to assess potential ecological changes in response to changes in the global climate induced by human activity. We suggest that the park take an active role in establishing permanent vegetation plots for monitoring changes in these sensitive plant populations. One such study (Lesica and McCune 1989) is already in progress.

\section{$\checkmark \quad$ STUdY AREA}

Glacier National Park was established by an act of Congress in 1910 to preserve the rugged mountain scenery it afforded (Runte 1987). The park contains parts of two mountain ranges: the Livingston and Lewis Ranges. These ranges were built by the upthrusting of sediments laid down during the Mesozoic. Some rock layers in the range are Precambrian in origin. During the Pleistocene, most of the park was covered with glaciers, and the remnants of these glaciers still exist at high elevations. Elevation ranges from $960 \mathrm{~m}$ in some of the valley areas to over $2900 \mathrm{~m}$ on some of the mountain peaks. The western portions of the Lewis Range receive significantly higher amounts of rainfall than the eastern foothills region of the range. 
Table 1. Rare plant species with populations in Glacier National Park according to Lesica (1984).

Lycopodiaceae - Clubmoss family

Lycopodium alpinum L. Alpine clubmoss

L. obsurum L. Ground pine

Ophioglossaceae - Snake's-tongue fern family

Botrychium matricariaefolium (Doell.) A. Braun. Camomile grape-fern

B. montanum Wagner Mountain moonwort

B. paradoxum Wagner Peculiar moonwort

Polypodiaceae - Polypody-fern family

Cystopteris montana (Lam.) Bernh. Mountain bladder-fern

Dryopteris cristata (L.) Gray Buckler fern

Thelypteris phegopteris (L.) Slosson Northern beech-fern syn: Phegopteris polypodioides Fee

Asteraceae - Sunflower family

Artemesia norvegica var. saxatilis (Bess.) Jeps. Boreal sageword, boreal wormwood

Erigeron lanatus Hook. Wooly daisy

Townsendia condensata Eat. Cushion townsendia

Brassicaceae - Mustard family

Draba fladnizensis Wulfen Austrian whitlow-wort

Ericaceae - Heath family

Vaccinium myrtilloides Michx. Myrtle-leaved huckleberry

Fabacae - Pea family

Hedysarum alpinum var. americanum Michx. American sweetvetch syn: H. americanum (Michx.) Britt.

Lathyrus bijugatus White Pinewoods sweetpea

Oxytropis campestris var. columbiana (St. John) Barneby Columbia River crazyweed

O. podocarpa Gray Stalked-pod crazyweed

Fumariaceae - Fumitory family

Corydalis sempervirens (L.) Pers. Pink corydalis syn: Capnoides sempervirens (L.) Borkh. 
Table 1. con't

Gentianaceae: Gentian family

Gentiana glauca Pall. Glaucous gentian

G. propinqua Richards Four-parted gentian

Lentibulariaceae - Bladderwort family

Pinguicula vulgaris L. Common butterwort, butterwort

Utricularia intermedia Hayne Mountain bladderwort

Paperveraceae - Poppy family

Papaver pygmaeum Rydb. Alpine glacier poppy, dwarf alpine poppy

Ranunculaceae - Buttercup family

Delphinium burkei Greene Meadow larkspur

Ranunculus gelidus Kar. \& Kir. Arctic buttercup

syn: $R$. ramulosus Jones

R. pedatifidus Smith Birdfoot buttercup

Salicaceae - Willow family

Salix barrattiana Hook. Barratt's willow

S. serissima (Bailey) Fern. Fall willow

Scrophulariaceae - Figwort family

Castelleja occidentalis Torr. Western paintbrush

Euphrasia arctica var. disjuncta (Fern. \& Wieg.) Cronq. Northern eyebright

Violaceae - Violet family

Viola renifolia Gray Kidney-leaved violet

Cyperaceae - Sedge family

Carex chordorrhiza L. Rope-root sedge

C. Eleusinoides Turcz. Goose-grass sedge syn: $C$. plectocarpa Herm.

C. Lenticularis var. dolia Michx. Kellogg's sedge

C. livida (Wahl.) Willd. Pale sedge

C. petricosa Dewey Rock sedge

C. saxatilis $\mathrm{L}$. Russet sedge

Eriophorum viridicarinatum (Engelm.) Fern. Green-keeled cottongrass

Kobresia simpliciuscula (Wahl.) Mack. Simple kobresia

Scirpus hudsonianus (Michx.) Fern. Hudson's Bay bulrush syn: E. alpinum L.

S. subterminalis Torr. Waterbulrush, water clubrush 
Table 1. con't

Juncaceae - Rush family

Juncus castaneus Smith Chestnut rush

J. triglumis var. albescens Lange Three-flowered rush syn: J. albescens (Lange) Fern.

Liliaceae - Lily family

Allium fibrillum Jones Fringed onion

Erythronium grandiflorum var. candidum (Piper) Abrams White glacier-lily*

Tofieldia pussilla (Michx.) Pers. Little false asphodel

syn: $T$. palustris Huds.

Orchidaceae - Orchid family

Cypripedium passerinum Richards Spotted lady's slipper

Epipactis gigantea Dougl. Giant helleborine

syn: Serapias gigantea (Dougl.) Eat.

Goodyera repens (L.) R. Br. Western rattlesnake plantain

Poacae - Grass family

Elymus innovatus Beal Boreal wildrye

Festuca ovina var. vivipara L. Viviparous sheep fescue, bulbiferous sheep

fescue; syn: $F$. vivpara (L.) Sm.

The diversity of geology and climate has lead to a large degree of ecological diversity in the Park. The eastern portion of the park below $1200 \mathrm{~m}$ is characterized by prairies. At elevations below 1800 $\mathrm{m}$, various coniferous forest types are found. Slopes are generally dominated by Douglas fir (Pseudotsuga menziesii), lodgepole pine (Pinus contorta), and western larch. Higher valleys have Engelmann spruce (Picea engelmannii) and subalpine fir (Abies lasiocarpa), while lower, more mesic valleys support western redcedar and western hemlock. Above 1800 $\mathrm{m}$ forests tend to be stunted due to high winds and cold conditions. At elevations greater than $2000 \mathrm{~m}$ but below $2700 \mathrm{~m}$, alpine tundra vegetation predominates.

Because of its geographical location and unique combination of ecosystems, GLAC contains a number of populations of rare plant species. Most of these populations are representatives of species whose geographical range boundaries exist in or near the park (Lesica 1984). However, at least two populations appear to be restricted only to the park itself.

\section{$\checkmark \quad$ MeTHODS}

Plant populations that were identified by Lesica (1984) as being rare in GLAC formed the basis of this study (Table 1). We took Lesica's list and initiated an intensive literature search to identify life history traits of each species. The Fire Effects Information System (FEIS) coordinated by William Fischer of the USDA Forest Service Intermountain Fire Sciences Laboratory, Intermountain Research Station, in Missoula, Montana maintains a data base on life history and management information of species of plants in the northwestern U.S. None of the species found in Table 1 were in the FEIS when we initiated our research. However, the FEIS employs an extensive literature searching system. Williams spent the summer of 1990 at the Fire 
Sciences Library using their literature searching system to locate references on the species in Table 1 . A total of 162 references were obtained during this literature search. In return for the use of the literature searching system, we compiled life history and management information in the proper format for entry into the FEIS. Entry of the data we collected for the FEIS was recently completed by the Forest Service.

We used the information gathered in the literature search to classify each species according to a number of life history characteristics. Twelve categories were used in this classification. Five categories referred to processes affecting population recruitment rates: fruit type, pollinator, reproductive mode, longevity, and dispersal agent. Five categories were related to habitat selection: successional stage, life form, soil type, soil moisture, and habitat type. Two additional categories contained management information: response to fire and value. Descriptions of the specific levels of these categories are given in Table 2.

Locations of populations for each species in GLAC were obtained from information recorded in Montana Natural Heritage Program (1990) and from an unpublished map compiled by $P$. Lesica for GLAC. The locations of each population were plotted out on a topographic map of GLAC (USGS 1968). These locations were then digitized by the University of Utah Digit Lab and stored in a Geographical Information System (GIS). Data on life history attributes of each species that had been obtained from the literature search were then associated with each population in the GIS. These data were used to obtain maps of the distribution of species with particular life history attributes in the park.

As human activities increasingly change ecological systems across the world, a number of changes to the ecology of the GLAC ecosystem can be expected. Pollution is having a number of direct effects on continental ecosystems. Probably the most widespread of these effects result from acidification of precipitation due to increased levels of sulpher dioxide and other gasses (Kennedy 1986, Reuss and Johnson 1986, Binkley et al. 1988). An indirect effect of increased levels of carbon dioxide and other gasses in the atmosphere has been to increase average temperatures across the globe (Abrahamson 1989, Leggett 1990). Changes in climatic patterns are likely to be induced by such increased temperatures (Schneider 1990). More localized effects on the GLAC ecosystem come from physical disturbances due to human activities in and around the park. Increased numbers of visitors in the park will increase the likelihood of trampling and similar disturbances to understory vegetation. Human activity also increases the likelihood of fires accidentally being started. Biological disturbances to park vegetation result from competition or other biological effects induced by introduced exotic species. Finally, as development increases in and around the park, the GLAC ecosystem may become more fragmented, decreasing the probability of population dispersal of species rare in the park. This may eventually lead to declines in populations that are being maintained by emigration. Each of these potential changes to the GLAC ecosystem will effect populations of rare species in the park. We attempted to evaluate these potential effects by using the life history information to identify how many species would be effected by these changes and where in the park such effects were most likely to be felt.

\section{- RESUlts AND Discussion}

\section{AVAILABLE DATA BASES}

In our literature search, we encountered several sources of computerized information on plant life histories. These data bases are run by several different government agencies, and Park personnel should be aware of them in future efforts to locate information on plant species in the park. The first data base we encountered was the Plant Information Network (PIN). This was a data base originally set up by the Western Energy and Land Use Team of the US Fish and Wildlife Service located in Fort Collins, Colorado. This initial effort to identify characteristics of plant species that might be useful in management has apparently not been maintained, although there is a computer tape with a program for searching the database that still exists.

The Fire Effects Information System, mentioned above, is maintained by the U.S. Forest Service Intermountain Fire Sciences Laboratory. We chose to use this system to search the primary literature for information used in this report because the literature search capabilities of the system. Since the FEIS contained no previous information on the study plant species (Table 1) were entered into the data base 
Table 2. Categories of life history criteria used to summarize information on the life histories of rare plant species in Glacier National Park.

\section{Fruit type}

$1=$ Achene

2 = Coryopsis

3 = Legume

4 = Capsule

$5=$ Spore

$6=$ Silicle

$7=$ Follicle

8 = Samara

\section{Pollinator}

$1=$ Wind

$2=$ Insect

$3=$ Bird

$4=$ Self

Successional Stage

$1=$ Pioneer

2 = Mid-seral

3 = Late-seral

\section{Life Form}

$1=$ Grass

2 = Forb

$3=$ Shrub

Longevity

$1=$ Annual

2 = Biennial

3 = Perennial

\section{Response to Fire}

$1=$ Decreaser

$2=$ Sprouter

$3=$ Pioneer

$4=$ Low fire regime

Soil Type

1 = Rocky slope

2 = Boggy

$3=$ Organic

4 = Sandy loam

$5=$ Variety

$6=$ Fertile, high moisture capacity

Primary Reproductive

Mode

$1=$ Sexual

$2=$ Vegetative

$3=$ Both

$\underline{\text { Soil Moisture }}$

$1=$ Wet

$2=$ Dry

$3=$ Shallow

4 = Rocky

\section{Habitat Type}

$1=$ Alpine

$2=$ Spruce/fir

$3=$ Douglas fir

$4=$ Cedar/hemlock

$5=$ Bunch grass

6 = Alpine, spruce/fir

\section{Dispersal agent}

$1=$ Wind, gravity

$2=$ Animal

$\underline{\text { Value }}$

$1=$ Rehabilitation

2 = Forage

3 = Shelter, nesting

$4=$ Rehabilitation and forage

$5=$ Rehabilitation and shelter, nesting after the literature search was completed.

Another data base that contains information about GLAC plants is the Montana Natural Heritage Program. this program is administered by the Montana State Library, and contains information about locations of populations and some information about site locations and conditions. The contact person for this data base is Margaret Beer, Montana State Library, Helena, Montana. Another data base that we encountered, but have little information on is the National Park Service Common Data Base. A 
part of that data base, called NPFLORA, has or will have information on the flora of all national parks. The data we assembled in our literature search were input into a GIS. This data base has been delivered to GLAC personnel on a floppy diskette in a format compatible with the park's GIS.

\section{PLANT POPULATIONS}

Rare plant populations were not randomly distributed throughout GLAC, but occurred in several distinct concentrations. The largest concentration of rare plant populations was in the Logan Pass area. This area had over 30 different populations representing 28 different species. Populations in this region are more or less evenly distributed from the Piegen Pass region southwest to Hidden Lake. East of this group of populations is a small cluster of populations near the origin of Boulder Creek in the Siyeh Pass/Preston Park area. Many of the same species found in the Logan Pass cluster are also found in Siyeh Pass cluster. A third group of populations is found south of the Logan pass cluster along the glaciers that follow the continental divide in the chain of peaks from Mt. Logan to Mt. Brown. Many of the same species are represented in these clusters. For example, alpine glacier poppy (Papaver pygmaem) and little false asphodel (Tofielldia pusilla) both have populations in each of these three clusters. A number of the species represented in these clusters also have populations scattered in other high alpine areas of the park. This group of species occurring in the high alpine areas of the park appears to represent the largest group of rare species in the park.

Generally, species found in these high alpine areas tend to be associated either with alpine or alpine/fir habitat types. Most of these species tend to be perennial forbs or grasses found in wet or boggy soils or on rocky slopes. Most are insect pollinated, or more infrequently, wind pollinated, and reproduce primarily by sexual means, although a number of species will also propagate vegetationally. Most of these species form dry, dehiscent fruits, such as capsules, but several have indehiscent fruits, such as achenes. Few of the species are of any economic value, and those that are tend to be species that have some value as forage. Generally, the species found in the alpine areas are those that tolerate only a low fire regime. Since most species are in moist soils or rocky outcrops, it is unlikely that they are affected in any degree by fire.
A second significant cluster of species is found in the McGee Meadows area northwest of Lake McDonald and northeast of the Apgar Mountains. This area has extensive bogs and forms a unique habitat. Species which inhabit this region tend to be found in wet or shallow soils of high moisture content. All are perennial grasses or forbs. Most species propogate by sexual reproduction, though some employ primarily vegetative propogation. Species are wind or insect pollinated. The species in the McGee Meadows area generally tend to be species that require a low fire regime. Since they are generally found in areas with boggy or wet soils, this is not surprising. The species generally do not have any significant value in management.

Perhaps the most striking property of most of the rare plant populations in GLAC is that they are either located in riparian areas or are associated with them. Populations of rare plants are distributed throughout the alpine areas of the Lewis and Livingston Ranges, but are concentrated in the wet alpine areas in and near Logan Pass. The second major concentration of rare plant populations is in the boggy areas of McGee Meadows.

\section{POTENTIALRESPONSES TOENVIRONMENTAL CHANGE}

In this section we consider changes that are likely to occur in GLAC ecosystems as a result of human activities. Many of these potential changes are linked to alterations in global ecosystems that may have complex effects in local ecosystems (e.g. Bazzazz and Williams 1991). Although the existing information is inadequate to make accurate predictions of changes that might occur, the following general descriptions of potential impacts should provide a starting point for more detailed investigations.

ACID RAIN - Massive amounts of gasses and particulate matter have been released into the earth's atmosphere by industrialization. The GLAC ecosystem may be relatively isolated from nearby sources of such pollutants, but the massive amounts released often cause subtle changes in precipitation over wide areas, most notably decreasing the $\mathrm{pH}$ (increasing the acidity) of rain and snow (Binkley et al. 1988). Increases in the acidity of precipitation have a number of effects on ecosystems. Acidic precipitation intercepted in the canopy of a forest increases the rate at which nutrients are leached from 
leaves, although trees can partially compensate physiologically for such leaching (Boerner 1984). More significantly, acidic precipitation can increase soil acidity, which in turn decreases nutrient content and increases concentration of aluminum cations to toxic levels (Kennedy 1986, Reuss and Johnson 1986, Binkley et al. 1988, Smith 1990).

Acidification of soils in GLAC over a long period of time may have profound effects on rare plant populations. Fourty five percent of the rare species in this study occur in shallow soils, and $35 \%$ are confined to rocky slopes. Such species exist in soils in which nutrients are likely to be leached relatively rapidly. The major concentration of these species, as described above, is in the high alpine and subalpine areas in and around Logan Pass. A large proportion of rare species (37\%) occur in wet, boggy soils. Such soils tend to be more acidic than normal, they have little ability to buffer increased acid deposition by precipitation. In GLAC, the bogs in McGee Meadows area will be most affected by such changes. In both the Logan Pass and McGee Meadows areas, acid precipitation would result in declines in rare plant populations as a consequence of losses in soil fertility. If acidification is severe enough, replacement of lost vegetation would occur very slowly.

GLOBAL WARMING - Another affect of increased industrialization is increased amounts of carbon dioxide, methane, and other gasses in the atmosphere. These gasses share the common property of absorbing infrared (heat) radiation reflected from the earth's surface. The consequence of this is that global temperatures and the climatic patterns that they generate may be altered (Hansen 1989, Leggett 1990). Changes in global climate patterns will have profound consequences for continental ecosystems. Measurable increases in atmospheric carbon dioxide have been correlated with increased in average global temperatures (Hansen 1989). A number of consequences are likely to ensue. First, as temperatures warm, the geographic distributions of species will generally shift northward following temperature extremes (Peters 1989). This will result in a contraction of biomes that predominate cooler latitudes. Altitudinal zones corresponding to cooler biomes will shift to higher elevations, contricting and fragmenting montane habitats. Increased temperatures will change water cycles, particularly in peatland habitats (Gorham 1991), leading to decreases in soil moisture. The rapidity of such changes relatively to climate changes associated with the decline of glaciers suggest that significant successional changes may be induced in coniferous forest biomes (Long and Hutchin 1991). Unfortunately, weed species often exceed ability of native species to respond to elevated levels of carbon dioxide, so successional changes may be dominated by increases in weedy species and exotics rather than native species adapted to warmer temperatures (Long and Hutchin 1991).

Changes in global climates that lead to increased temperatures in coniferous forest biomes will greatly impact the rare plant populations of GLAC. Changes in water tables associated with warming would decrease the availability of wet, boggy soil types on which most of the rare plant populations in the McGee Meadows areas are located. Shifting of life zones to higher elevations would contract the area of alpine and spruce forest habitats in the park. Seventy eight percent of the rare plant populations in GLAC are associated with these habitats. Significant alterations in the alpine and spruce forest life zones in GLAC might result in losses of many rare plant species for at least two reasons. First, contraction of life zones, particularly the alpine zone, would further isolate populations of these species and would decrease the total number of individuals that could be contained in these populations. This would in turn increase the likelihood of stochastic extinction (Lande 1988, see also papers in Soule 1987). Second, increased vigor of populations of weed species as a result of elevated carbon dioxide levels in the atmosphere might result in populations of rare plant species being outcompeted by weeds during secondary succession in shifted life zones.

As GLAC receives a greater number of visitors, greater physical disturbances are likely in and around the park. Two types of physical disturbances may have important consequences for rare species. First, increased human activity will increase the number of persons using trails in the park. This increases the likelihood that populations of rare plants will be encountered. Since many of these populations are found on shallow soils at higher elevations, increased activity may result in increased weathering of these soils. In the McGee Meadows area, increased activity near bogs may result in trampling of vegetation. The increased compaction of these soils may decrease their ability to hold water. Second, as human activity increases, there is an increased likelihood of human started fires. Most of the rare 
species in this study (59\%) require low fire regimes or decrease after fire. Both of these physical impacts will interact with larger scale climate change and acidic precipitation to threaten populations of rare plant species in GLAC. As drier climatic conditions result from global warming, vegetation communities in GLAC may become more susceptible to fire. Decreased fertility of soils in response to acid precipitation may make them more sensitive to erosion and weathering stimulated by higher frequencies of hiking.

Nearly all of the rare plant species in GLAC occur in small, isolated populations at or near the edge of their geographic ranges (Lesica 1984). Such populations may be maintained in a large degree by immigration from larger populations outside of the park (see, e.g., Maurer and Brown 1989). The long term persistence of such populations may therefore depend on the maintenance of dispersal from populations outside the park. As development and use of natural resources outside GLAC increase, it is likely that the park itself may become more like an isolated island (MacArthur and Wilson 1967). If development isolates the park, it is likely that rates of dispersal into the park may be decreased. Virtually all of the rare plant species we studied are wind dispersed, so distance from dispersal sources may have a major impact on the persistence of their populations. In addition, half of the species are pollinated by insects or birds. Thus, in order for these plant species to be able to reproduce sexually, populations of pollinators must be maintained at adequate levels in the park. Here again, increased isolation of the park by development may prevent pollinators from locating it or maintaining large enough populations to adequately pollinate their respective plant populations.

\section{$\checkmark \quad$ CONCLUSIONS}

Management of the resources of GLAC to maintain its uniqueness and value as an ecological reserve requires special attention to the McGee Meadows and Logan Pass areas. To date, these areas have the highest known concentrations of rare plant populations. Since these areas are created by unique combinations of geological, climatic, and ecological conditions, it is important that further research be carried out to identify what makes these areas so unique. Ecosystem level studies that are aimed at identifying the processes that maintain such high concentrations of rare plant populations should be encouraged. The results of such studies, when related to life history information such as that included in this report, should allow GLAC managers to formulate strategies to protect these habitats.

A second concern regarding the populations of rare species in the park is current plans for monitoring populations. At least one effort is currently underway for monitoring plant populations in the Logan Pass area (Lesica and McCune 1989). The results of this study should be integrated very carefully with management plans in the Park. Options such as limiting access to sensitive areas, planning development of park roads and structures to protect these areas, and developing a flexible management strategy to mitigate changes in the park should be considered very carefully by managers. With this report and the work of Lesica (1984), it is clear which areas in the park are important reservoirs of biodiversity. It is now critical that Park managers and scientists use this information to develop strategies for coping with ecological change in the park.

\section{$\checkmark \quad$ LITERATURE CITED}

Abrahamson, D. E., ed. 1989. The challenge of global warming. Island Press, Washington, D.C.

Bazzazz, F. A., and W. E. Williams. 1991. Atmospheric $\mathrm{CO}_{2}$ concentrations within a mixed forest: implications for seedling growth. Ecology 72:12-16.

Binkley, D., C. T. Driscoll, H. L. Allen, P. Schoeneberger, and D. McAvoy. 1988. Acid deposition and forest soils. Springer-Verlag, New York.

Boerner, R. E. J. 1984. Foliar nutrient dynamics and nutrient use efficiency of four deciduous tree species in relation to site fertility. Journal of applied Ecology 21:1029-1040.

Gorham, E. 1991. Northern peatlands: role in carbon cycle and probable responses to climatic warming. Ecol. Appl. 11:182-195. 
Hansen, J. E. 1989. The greenhouse effect: impacts on current global temperature and regional heat waves. Pages 35-43 In: Abrahamson, D. E., ed. The challenge of global warming. Island Press, Washington, D.C.

Kennedy, I. R. 1986. Acid soil and acid rain. Research Studies Press, Wiley, New York.

Lande, R. 1988. Genetics and demography in biological conservation. Science 241:14551460.

Leggett, J., ed. 1990. Global warming. Oxford University Press, Oxford.

Lesica, P. 1984. Rare vascular plant populations of Glacier National Park, Montana. Unpublished Report to Glacier National Park.

Long, S. P., and P. R. Hutchin. 1991. Primary production in grasslands and coniferous forests with climatic change: an overview. Ecol. Appl. 1:139-156.

Maurer, B. A., and J. H. Brown. 1989. Distributional consequences of spatial variation in local demographic processes. Annales Zoologici Fennici 26:121-131.

Montana Natural Heritage Program. 1990. Special plant occurrences: Glacier National Park, Montana. Montana State Library, unpublished computer listing, June 29, 1990.
Peters, R. L. 1989. Effects of global warming on biological diversity. Pages 82-95 In: Abrahamson, D. E., ed. The challenge of global warming. Island Press, Washington, D.C.

Reuss, J. O., and D. W. Johnson. 1986: Acid deposition and the acidification of soils and waters. Springer-Verlag, New York.

Runte, A. 1987. National parks: the American experience. University of Nebraska Press, Lincoln.

Schneider, S. H. 1990. The science of climatemodelling and a perspective on the globalwarming debate. Pages 44-67 In: Leggett, J., ed. Global warming. Oxford University Press, Oxford.

Smith, W. H. 1990. Air pollution and forests. 2nd ed. Springer-verlag, New York.

Soulé, M. 1988. Viable populations for conservation. Cambridge University Press, Cambridge.

USGS. 1968. Topographic map of Glacier National Park. United States Department of the Interior Geological Survey, Washington, D.C. 